\title{
Introduction by the Guest Editors - On-board Protection of Merchant Vessels against Piracy: Models of Regulation
}

\author{
Birgit Feldtmann, Christian Frier \& Paul Mevis*
}

\begin{abstract}
'We may be dealing with a $17^{\text {th }}$ century crime, but we need to bring $21^{\text {st }}$ century solutions to bear.'

Former US Secretary of State Hillary Clinton in response to the Maersk Alabama incident in 2009. ${ }^{1}$
\end{abstract}

\section{Why This Special Issue?}

Maritime piracy is commonly described as one of the oldest 'occupations' at sea. The international law on piracy has historically evolved in customary law and case law. ${ }^{2}$ After multiple attempts to craft legislation, it succeeded with the codification of piracy provisions in the 1958 Geneva Convention on the High Seas which is largely reprinted in the UN Convention of the Law of the Sea (UNCLOS). Interestingly, it can be argued that piracy has not really been a major topic in the legal debate in last half of the twentieth century. In fact, when drafting UNCLOS it was considered whether piracy should rather be conceived as a historic phenomenon no longer of real relevance. ${ }^{3}$ Despite those considerations, the UNCLOS' articles concerning piracy were tested in the twenty-first century, when the surge in pirate attacks around the Horn of Africa and adjacent waters led to what is widely regarded as the modern era of piracy.

Contemporary piracy is a question of utmost relevance when taking into consideration the importance that seaborne transport has for the global economy. Around eighty per cent of world trade is carried by the international merchant fleet at some stage of the logistic chain of transport. The international merchant fleet comprises of 50,000 ships and employs around 1 million seafarers. Nevertheless, the fight against piracy cannot be

* Birgit Feldtmann is professor (mso) at the Department of Law, Aalborg University. Christian Frier is research assistant at the Department of Law, University of Southern Denmark. He obtained his PhD in Law in March 2019. Paul Mevis is professor of criminal law and criminal procedure at Erasmus University Rotterdam.

1. Cited from A.J. Shapiro, 'Counter-piracy Policy: Delivering Judicial Consequences'.

2. See M. Frostad, Voldelige Hav; Pirateri og jus (2016) 48-66.

3. See A. Petrig, 'Arrest, Detention and Transfer of Piracy Suspects: A Critical Appraisal of the German Courier Case Decision', in G. Andreone, G. Bevilacqua, G. Cataldi \& C. Cinelli (eds.), Insecurity at Sea: Piracy and Other Risks to Navigation (2013) 160. approached with economic interests only. Piracy is not a victimless crime, but a violent form of crime with severe consequences for seafarers and families. The fight against piracy is also about organising a safer and peaceful world by promoting and maintaining rule-of-law conditions in the countries and regions from where the pirates originate. Counter-piracy is also a form of crime control, using criminal law enforcement tools not only against pirates at sea but also against the kingpins who operate on shore.

Throughout history, the problems associated with maritime piracy and other attacks against vessels have repeatedly needed to be addressed by the international community and the shipping industry. Today, in the context of Somali piracy, this includes, inter alia, naval efforts and different forms of self-protection measures. In addition, more long-term solutions are addressed in the form of regional capacity building. ${ }^{4}$ From 2006 until 2011, the international community and the shipping industry witnessed a substantial increase in pirate attacks and successful hijackings in the wider Horn of Africa region. ${ }^{5}$ This led to discussions on whether there was a need for additional 'tools in the toolbox' to protect commercial ships. One of those tools discussed was the deployment of on-board protection: should vessels be protected by armed guards placed on-board commercial ships? And if this would be the case, should the guards be either state representatives (Vessel Protection Detachments [VPDs]) or alternatively private actors (Privately Contracted Armed Security Personnel [PCASPs])?

The discussion is complex and has partly been held at the international level. However, the final decision to permit armed guards or not is ultimately an issue which each flag state must determine. Accordingly, many flag states reacted to the situation by considering the questions at hand and, if necessary, by supplementing existing or crafting new legislation to accommodate the use of armed guards. Thus, flag states have chosen different approaches, which have led to a multitude of national models of regulation. Most of the models have now been

4. See the contribution by B. Feldtmann.

5. See B. Feldtmann, 'Fighting Maritime Piracy; On Possible Actions and Consequences', in T. Eger, S. Oeter \& S. Voigt (eds.), Economic Analysis of International Law; Contributions to the XIIIth Travemünde Symposium on the Economic Analysis of Law (March 29-31,2012) (2014) 174. 
in place for years, and it is therefore possible to reflect on the lessons learned.

\section{The Scope of This Special Issue}

The aim of this special issue is to examine and discuss a selection of national models of regulation pertaining to the use of armed guards as on-board protection. Perhaps this issue is no longer considered a burning issue, both with regards to the developments of pirate attacks off the coast of Somalia and with regards to other publications dealing with similar issues; however, it is still a very real issue with very serious consequences. ${ }^{6} \mathrm{We}$ believe that the issues at stake continue to be of great relevance and the need for on-board protection is a subject that is not going to go away. The current debate in the Netherlands clearly illustrates this. ${ }^{7}$ And even if Somali-based piracy appears, at least to a certain extent, to be contained, the problem is far from solved. Newer incidents and hijackings suggest that Somali-based piracy could regain its strength if the focus moves on and counter-piracy operations are terminated or considerably downsized. ${ }^{8}$ Furthermore, piracy and other types of attacks against maritime navigation are not only a phenomenon in the waters off the coast of East Africa. For example, the current situation in the Gulf of Guinea is of major concern to the shipping industry. ${ }^{9}$ This concern is supported by recent attacks and hijackings in the region. ${ }^{10}$ This means that the issue of on-board protection is still ongoing. Besides this, fundamental questions of (comparative) law might become clearer in a retrospective perspective, given the different models of regulation that have been developed in the designated countries. In this respect, the special issue may identify interesting questions for further research. The discussion could also be of relevance in other fields where public-private armed protection and the call for adequate regulation in the light of state responsibility is at stake.

Our perspective in this special issue is entirely a European one, as we are only dealing with European flag states. All of the chosen states perceive themselves as states with major shipping interests (even if their fleet is not among the largest). Furthermore, all of the states are members of the EU and the Council of Europe and share common international human rights obligations.

6. See e.g. the special issue of 46(2) Ocean Development \& International Law (2015).

7. See the contribution on the Netherlands by P.A.M. Mevis and S. Eckhardt.

8. NATO Operation Ocean Shield was, e.g. concluded in December 2016, available at: https://www.mc.nato.int/missions/operation-oceanshield.aspx

9. See Danske Rederier (Danish Ship Owners), 'Piracy', Policy Paper September 2017.

10. On the development see Oceans Beyond Piracy (OBP), 'The State of Maritime Piracy 2017', available at: http://oceansbeyondpiracy.org/ reports/sop/east-africa
All flag states have at some point taken active part in counter-piracy operations in the region of the Horn of Africa and in the international fora for cooperation, such as the Contact Group on Piracy off the Coast of Somalia (CGPCS). ${ }^{11}$

The European regulatory models discussed in this special issue are those of Denmark, Germany, Italy and the Netherlands. These states have been chosen because they could be perceived as a kind of 'blueprint' for quite different approaches: Denmark has allowed a PCASP model with very little state control and limited explicit regulation. Germany has chosen a PCASP model with quite tight regulation and state control by crafting a comprehensive legal framework, whereas Italy first introduced a hybrid model, but later turned to an exclusive PCASP model. Finally, for a considerable time, the Netherlands opted for an exclusive VPD model ('VDP only') but will soon introduce a hybrid model. Consequently, the models of regulation discussed in this special issue differ in view to what could be called the 'level of privatisation'; we will return to this question in the final contribution of this special issue.

\section{The Content of This Special Issue}

The different national regulatory models presented and discussed in this special issue have, as mentioned earlier, been created at the flag state level. Nevertheless, the development of those regulations did not materialise completely isolated from the international sphere. They were developed within the general principles and the framework of the international law of the sea. This special issue therefore begins with a contribution on the international perspective in connection with the issue of on-board protection and flag state regulation. This contribution by Birgit Feldtmann serves two purposes. First, it aims at briefly introducing the problem of piracy, the issues at stake and the reactions towards the problems at hand at the international level. Second, it discusses the international legal framework under which flag states draft their regulation of the matter at hand, as well as relevant international soft law instruments influencing the national level.

The main part of this special issue looks at the four country reports in the following order: the Danish model by Christian Frier, the German model by Tim R. Salomon, the Italian model by Giorgia Bevilacqua and the Dutch model by Paul Mevis and Sari Eckhardt. This order is based on the intensity of the above-mentioned

11. On CGPCS, see U. Trolle Smed, 'Small States in the CGPCS: Denmark, Working Group 2, and the End of the Debate on an International Piracy Court', Working Paper of the Lessons Learned Project of the Contact Group om Piracy off the Coast of Somalia (CGPCS), s. $3 \mathrm{f}$, available at: http://www.lessonsfrompiracy.net/files/2015/03/Smed-Small-statesin-the-CGPCS-Denmark.pdf and B. Feldtmann, 'Jura som et led i dansk aktivistisk udenrigspolitik til søs', Økonomi \& Politik 13, at 19-20 (2017). 
privatisation factors, starting with Denmark with its rather strong ties to the shipping industry, to delegation of competence and concluding with the Netherlands, which has (at least for the time being) a very low privatisation factor. The general similarity between the four flag states is that they have debated the questions at hand and allowed for some kind of on-board protection of merchant vessels. However, the chosen approaches towards on-board protection do vary quite strongly between these countries.

The four country reports do speak for themselves: the basic question to be answered in all of the country reports is what kind of on-board protection is allowed and how, and to which extent, this is regulated. The country reports differ in their structure to a certain extent. However, they all give a brief insight into the domestic discussions on the issues at hand and the development towards the chosen national approach. They all outline the legal framework for employing onboard protection and provide insight into the involvement of public authorities in the process. They also raise the specific question of the regulation of the use of force and the question of the relation and division of responsibilities between the master and the team leader to a certain extent. If relevant, the country reports are illustrated with specific examples and incidents within the chosen model.

The final contribution of this special issue is by Feldtmann, Frier and Mevis and reflects on some selected cross-cutting issues in connection with on-board protection of merchant vessels and the chosen approaches based on the country reports. It also highlights the perspective of the lessons learned so far.

\section{Some Concluding Remarks}

With this special issue of the Erasmus Lam Reviem, we hope to contribute to the wider discussion of maritime security and specifically to the debate on the practical solutions and legal instruments for dealing with the problem of maritime piracy (or other attacks on vessels) and to the debate on the use of force and the adequate regulation of the use of force.

The idea of this special issue project is closely linked to - and is a part of - the Danish research project 'Policing at Sea (PolSEA)' under the Danish Independent Research Fund. We are grateful that the Danish Independent Research Fund supports the PolSEA project and thereby made this publication possible.

We would also like to thank our authors for their valuable contributions; without their willingness to share their valuable knowledge and to invest their time and energy, this contribution would not be possible. Furthermore, we would like to thank the anonymous peer reviewers for their helpful comments. Finally, we would also like to thank the board of editors of the Erasmus Law Reviem for the opportunity to publish this special issue and for their support during the process.
Aalborg, Odense \& Rotterdam

Birgit Feldtmann, Christian Frier \& Paul Mevis 